\title{
ASSESSMENT OF INHALERS TECHNIQUE PROPER USE FOR PATIENTS WITH CHRONIC RESPIRATORY DISEASES IN PRIMARY AND SECONDARY CLINICS IN BABYLON CITY
}

\author{
NOOR HASSAN SHAMMER ${ }^{1}$, ALI SALIH BAAY ${ }^{2 *}$ \\ ${ }^{1}$ Babylon Health Directory, Babylon, Iraq. ${ }^{2}$ Department of Internal Medicine, College of Medicine, Babylon University, Babylon, Iraq. \\ Email: ali_salh64@yahoo.com
}

Received: 04 November 2017, Revised and Accepted: 02 December 2017

\begin{abstract}
Objective: Although the inhalers are the preferred method of medications delivery, evidences suggest that many patients are unable to use their inhalers effectively due to improper technique so patients must know the right way of their inhaler use. The aim of the study is to assess the patient's ability to use their inhalers properly, identify the most common error made, assess the benefit of single education session, compare the property of the use between the primary and secondary clinics patients, determine which type of the inhaler devices is associated with more errors, and to identify the association between the inhaler technique and the disease control.
\end{abstract}

Methods: Non-randomized interventional study was done on 100 inhaler users of three inhaler types (metered-dose inhaler [p MDI], Turbuhaler, or Handihaler) for chronic respiratory diseases. Inhaler technique was evaluated by a scoring system before and after single session of training.

Results: It had been shown that the current education about inhalers techniques was not sufficient. The response to single session of education was higher with high level of education, urban area, and specialized respiratory center. Better disease control with the better score. After training, the younger patients have higher score.

Conclusion: We conclude that we need to stress on the most reported defect, metered-dose inhaler had the lowest mean score; therefore, it needs more training. Furthermore, single class of training can be beneficial but need follow-up to see if this effect can be maintained.

Keywords: Inhaler, Proper technique, Chronic respiratory diseases, Babylon city.

(C) 2018 The Authors. Published by Innovare Academic Sciences Pvt Ltd. This is an open access article under the CC BY license (http://creativecommons. org/licenses/by/4. 0/) DOI: http://dx.doi.org/10.22159/ajpcr.2018.v11i3.23481

\section{INTRODUCTION}

Inhalers have the benefit of transmission of drug directly to the lungs with lower systemic side effect to use the lungs as a way for distribution of the drug systemically $[1,2]$.

Pulmonary delivery is a special way for delivering the medication systemically because the huge capacity of the alveoli which allows fast absorption in addition to the lacking of the first pass metabolism, profuse blood supply, and delicate blood-air wall [3]

In spite of being a good delivery way, most of the patients dislike inhaler and regard it as stigma in their live, the issue of diversity and perspectives of stigma has been addressed in various chronic illnesses including asthma. The stigma in asthma has caused considerable negative repercussions on social support, patients' daily functioning, and quality of life of asthma patients [4].

Like other medicines, not responding to the prescribed drugs can yield from bad adherence. In medication delivered by inhalers, bad adherence can result from no use, irregular or overuse of the inhaler or bad inhaler use technique $[2,3]$

Factors affect effectiveness [5]:

1. Efficacy of the drug.

2. How they are used which mean appropriate prescription, patients adherence and the use of the inhaler device adequately.

Patients more likely for improper use of the inhaler are as follows [5,6]:

- Children.

- Older adults.

- People with severe airflow limitation.

- Patients have more than the type of inhaler device.
Whatever the prescribed inhaler type, the patients at any age are unusual to practice the device properly unless adequate instructions are given, as practical demonstration and regular checking of the inhaler technique $[6,7]$

Moreover, benefits of inhaled therapy can be limited by inadequate inhalation maneuvering and inhaler handling. The main problem with inhalers is the inhalation technique, especially with pressurized metered-dose inhalers [8].

When used properly, inhalers give the smallest suitable dose of the medication to the target sites in the lungs directly, associated by more rapid starting of action of that medication with less systemic distribution that reduces the disadvantages of the drug.

Improper inhaler technique decreases the drug delivery to the lungs, wastes medication, affect the disease control, decreases life quality, increases admissions to the emergency units, and higher treatment costs [9]. National Review of Asthma Deaths in 2014 recorded not understanding along with improper inhaler use might contribute to the large number of asthma deaths during 2012

Temporal adherence depends on the patient perceptions of his disease, satisfaction in the treatment, the cost of the medication, and healthcare access $[10,11]$. While the adherence to the technique is due to lack of or forget the instructions [12].

Smart inhalers are an exciting new development that is being studied in clinical trials. They depend on Bluetooth technique to help the patients to remember to use their treatment and gather data to help guide care. In the future, smart inhalers could monitor and even correct a patient's inhalation technique [13]. 
Several studies have demonstrated that patients training on inhaler technique correct not only the technique but also compliance with the medications and, chiefly, the control of the disease $[14,15]$.

An useful way is the evaluation, the inhaler use technique of the patients by matching the steps of their technique to a list particular to their inhaler type followed by giving them written directions around their mistakes (as sticker on the device) [16]

Even after attaining the proper technique by training, the patients may miss these abilities by $2-3$ months, inhaler technique should be reassessed and teaching should be done again frequently [17].

All healthcare providers should be involved in this teaching practice: Primary healthcare doctors, lung consultants, physiotherapists, nurses, and pharmacologists.

To confirm beneficial inhaler use:

- Choose the most suitable device for the patient depending on well, joint and physical state and the financial issues also.

- Check inhaler procedure at every occasion with the checklist. Ask the patients to display to you their inhaler use.

- Correct using a physical demonstration, giving consideration to wrong steps and reassess the technique.

- Confirm that you have a definite list to each type of the inhalers (Global Initiative for Asthma 2017).

In this study up to our knowledge, it is the $1^{\text {st }}$ study to correlate the chronic respiratory disease control with the inhaler technique and to compare between three types of inhalers and with tow specialty levels clinic in Iraq.

\section{METHODS}

This study is conducted in the centers which is secondary specialized center (Marjan Medical City Respiratory Outpatient Clinic) and nonspecialized centers which are the primary healthcare centers in Babylon city during the period from the $1^{\text {st }} J a n u a r y$ to the $1^{\text {st }}$ August.

A randomized interventional study was done on 100 inhaler users (metered-dose inhaler [p MDI], Turbuhaler, or Handihaler) who were diagnosed previously to have asthma or chronic obstructive pulmonary disease by physicians according to the clinical data, pulmonary function test, and radiological imaging.

After informed consent, the use of each inhaler device was evaluated by asking the patients to demonstrate their inhalation technique using their inhaler device. We asked them to say each step as they performed it. Hence, that all the steps could be clearly observed. We performed special checklist for each type of inhaler involved in this study (Turbuhaler, p MDI, and Handihaler as shown in Tables 1-3, respectively) according to the National Asthma Council Australia was measuring the essential steps required for adequate drug delivery for each inhaler device and we gave a score for each step according to the importance of the step in delivering the medication to the lungs. The scoring system was viewed on respiratory committee in Babel city and it was acceptable. We used questioner about demographic data include age, gender, education level, duration of the use of the inhaler, the residence, and the type of the center. We asked them about their subjective evaluation of their symptoms control using asthma control test (ACT) score for asthmatic patients and chronic obstructive pulmonary disease (COPD) assessment test (CAT) score for patients with COPD. Then, we showed them the proper technique of the inhaler use using empty inhaler devices gave them instructions and reevaluated their use of the inhalers by the same scoring system. We compared the score before and after education.

\section{Inclusion criteria}

The patients 18 years old or older using p MDI, Turbuhaler, or Handihaler for 6 months duration or more who were not in exacerbation and were clearly diagnosed to have asthma or COPD.
Table 1: The using steps for Turbuhaler

\begin{tabular}{lll}
\hline S. No. & Steps & Checklist score \\
\hline 1 & $\begin{array}{l}\text { Unscrew and remove cover } \\
\text { Check dose counter }\end{array}$ & 1 \\
3 & $\begin{array}{l}\text { Keep inhaler upright while twisting } \\
\text { grip without shaking }\end{array}$ & 2 \\
4 & $\begin{array}{l}\text { Twist around and then back until } \\
\text { click is heard }\end{array}$ & 3 \\
& $\begin{array}{l}\text { Breathe out gently, away from the } \\
\text { inhaler }\end{array}$ & 1 \\
5 & $\begin{array}{l}\text { Place mouthpiece between teeth } \\
\text { without biting and close lips to form }\end{array}$ & 2 \\
6 & $\begin{array}{l}\text { good seal. Do not cover the air vents } \\
\text { Breathe in strongly and deeply }\end{array}$ & 3 \\
7 & $\begin{array}{l}\text { Hold breath for about 5 s or as long } \\
\text { as comfortable }\end{array}$ & 2 \\
8 & $\begin{array}{l}\text { Remove inhaler from mouth } \\
\text { Breathe out gently away from the } \\
\text { inhaler }\end{array}$ & 1 \\
10 & $\begin{array}{l}\text { If an extra dose is needed, repeat } \\
\text { steps 2-10 }\end{array}$ & 1 \\
11 & $\begin{array}{l}\text { Replace cover } \\
\text { Total }\end{array}$ & 1 \\
12 & & 20 \\
\hline
\end{tabular}

Table 2: The using steps for MDI

\begin{tabular}{lll}
\hline S. No. & Steps & List score \\
\hline 1 & Remove cap & 1 \\
2 & Hold inhaler upright and shake well & 3 \\
3 & $\begin{array}{l}\text { Breathe out gently, away from the inhaler } \\
4\end{array}$ & 1 \\
& $\begin{array}{l}\text { Put mouthpiece between teeth without } \\
\text { biting and close lips to form good seal }\end{array}$ & 2 \\
5 & $\begin{array}{l}\text { Start to breathe in slowly through mouth } \\
\text { and, at the same time, press down firmly on }\end{array}$ & 3 \\
& $\begin{array}{l}\text { canister } \\
6\end{array}$ & Continue to breathe in slowly and deeply \\
7 & $\begin{array}{l}\text { Hold breath for about 5 s or as long as } \\
\text { comfortable }\end{array}$ & 4 \\
8 & $\begin{array}{l}\text { While holding breath, remove inhaler from } \\
\text { mouth }\end{array}$ & 1 \\
9 & $\begin{array}{l}\text { Breathe out gently, away from the inhaler } \\
10\end{array}$ & 1 \\
& $\begin{array}{l}\text { If an extra dose is needed, repeat steps } \\
\text { 2-12 }\end{array}$ & 1 \\
& $\begin{array}{l}\text { Replace cap } \\
\text { Total }\end{array}$ & 1 \\
\hline
\end{tabular}

MDI: Metered-dose inhaler

\section{Sample size}

The sample size was estimated according to the following equation:

$$
n=\frac{1.96^{2} * p(1-p)^{2}}{d^{2}}
$$

Where: $n=$ sample size, $\mathrm{p}=$ the proportion $=5 \%$ (which is the prevalence of chronic respiratory disease in Iraq according to Iraq Family Health Survey 2006/7)

$\mathrm{d}=$ relative precision $=0.05$. Hence, the total sample size which is required according to this equation will be:

$$
n=\frac{1.96^{2} * 0.05(1-0.05)^{2}}{0.05^{2}}
$$

Ethical approval:

- Study was discussed and approved by the ethical committee in Babylon University, College of Medicine. 
- Patient's verbal consents were obtained before interviewing after explaining of the study to them.

- Official agreement was obtained from Babylon Health Directorate.

\section{RESULT}

The study was done on 100 inhaler users distributed as shown in Tables 4-10, Figs. 1 and 2.Fig. 2: Correlation between inhaler technique score before instructions and chronic obstructive pulmonary disease (COPD) assessment test score for COPD patients.

\section{DISCUSSION}

Many evidences from randomized clinical trials have shown that patients' inhaler technique can be improved by education from a health professional [18] or other individual being trained about the proper use of the inhaler [19].

The percentage of mistakes differs largely among the studies, relating to the study standards, inhaler type, the patient education level, and other factors. However, many studies have found that the rate of incorrect use was about $90 \%$ [20]. In this study, there was significant association between the higher score (before and after training) and the higher level of education $(\mathrm{p} \leq 0.001)$, urban residence $(\mathrm{p}=0.001,0.013)$, attendance of the specialized respiratory center $(\mathrm{p}=0.012,0.015)$, and the use of the Handihaler type of inhaler $(p=0.01,0.003)$. Furthermore, there was significant relationship between the higher score of the technique of the inhaler use and the disease control as evaluated by ACT score for asthmatic patients and CAT score for COPD patients ( $p<0.001$ for both diseases). There was no significant statistical relationship between the inhaler technique score with the age, gender, and the duration of the use of the inhaler.

A local study showed that patients with low level of education had more inhaler use mistakes and there was no significant association between the proper inhaler maneuver and gender of the patient or diagnosis of the disease [3], which are compatible with the results of the current study.

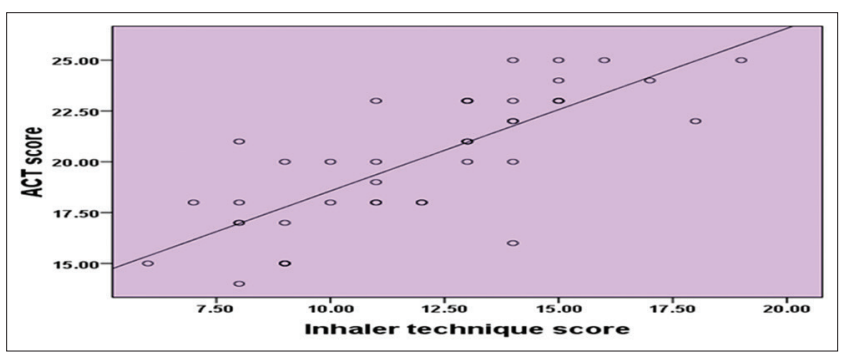

Fig. 1: Correlation between inhaler technique score before instructions and asthma control test score for asthmatic patients. There was significant negative linear correlation between inhaler technique score and chronic obstructive pulmonary disease assessment test score $\left(\mathrm{r}=-0.638, \mathrm{p}=<0.001^{*}\right)$

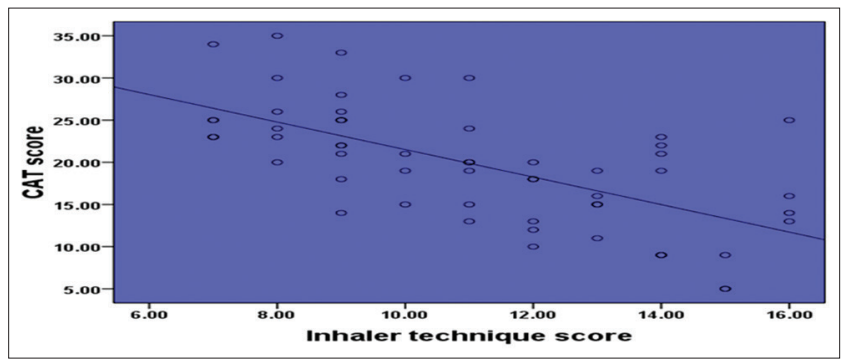

Fig. 2: Correlation between inhaler technique score before instructions and chronic obstructive pulmonary disease (COPD) assessment test score for COPD patients. There were significant differences between means of inhaler technique score after giving instructions by age, residence, and educational level
While in contrast to this study, they found that using Turbuhaler, older patients ( $>60$ years old), and shorter duration of use were significantly associated with poor inhaler technique these differences may be due to different standards, selection criteria, sample size, and shorter time.

Table 3: The using steps for Handihaler

\begin{tabular}{lll}
\hline S. No. & Step & Checklist score \\
\hline 1 & Open cap & 1 \\
2 & $\begin{array}{l}\text { Flip open mouthpiece } \\
\text { Remove capsule from blister and place }\end{array}$ & 1 \\
3 & $\begin{array}{l}\text { in chamber } \\
\text { Close mouthpiece in chamber }\end{array}$ & 1 \\
4 & $\begin{array}{l}\text { Press green piercing button in once } \\
\text { and release (do not shake) }\end{array}$ & 3 \\
5 & $\begin{array}{l}\text { Breathe out gently, away from the } \\
\text { inhaler }\end{array}$ & 1 \\
6 & $\begin{array}{l}\text { Place mouthpiece between teeth } \\
\text { without biting and close lips to form }\end{array}$ & 2 \\
7 & $\begin{array}{l}\text { a seal } \\
\text { Breath in slowly and deeply, so capsule } \\
\text { vibrate }\end{array}$ & 3 \\
Keep breathing as long as possible & 2 \\
9 & $\begin{array}{l}\text { While holding breath, remove inhaler } \\
\text { from the mouth }\end{array}$ & 1 \\
11 & $\begin{array}{l}\text { Breath out gently, away from the } \\
\text { inhaler }\end{array}$ & 1 \\
12 & $\begin{array}{l}\text { Repeat steps from 7 to 11 take the full } \\
\text { dose }\end{array}$ & 1 \\
13 & $\begin{array}{l}\text { Open mouthpiece and remove capsule } \\
\text { Close mouthpiece and cap }\end{array}$ & 1 \\
Total & 20 \\
\hline
\end{tabular}

Table 4: Distribution of patients according to sociodemographic variables

\begin{tabular}{|c|c|c|}
\hline \multicolumn{3}{|c|}{ Sociodemographic characteristics } \\
\hline Age (years) & $(48.12 \pm 18.59)$ & $(19-79)$ \\
\hline \multicolumn{3}{|l|}{ Gender } \\
\hline Male & 48 & $48 \%$ \\
\hline Female & 52 & $52 \%$ \\
\hline Total & 100 & $100 \%$ \\
\hline \multicolumn{3}{|l|}{ Residence } \\
\hline Urban & 49 & $49 \%$ \\
\hline Rural & 51 & $51 \%$ \\
\hline Total & 100 & $100 \%$ \\
\hline \multicolumn{3}{|l|}{ Educational level } \\
\hline Uneducated & 14 & $14 \%$ \\
\hline Primary & 34 & $34 \%$ \\
\hline Secondary & 35 & $35 \%$ \\
\hline Higher education & 17 & $17 \%$ \\
\hline Total & 100 & $100 \%$ \\
\hline \multicolumn{3}{|l|}{ Diagnosis } \\
\hline Asthma & 43 & $43 \%$ \\
\hline COPD & 57 & $57 \%$ \\
\hline Total & 100 & $100 \%$ \\
\hline \multicolumn{3}{|l|}{ Centers } \\
\hline Specialized & 60 & $60 \%$ \\
\hline Non-specialized & 40 & $40 \%$ \\
\hline Total & 100 & $100 \%$ \\
\hline \multicolumn{3}{|l|}{ Duration of use } \\
\hline 6-12 months & 46 & $46 \%$ \\
\hline$>12$ months & 54 & $54 \%$ \\
\hline Total & 100 & $100 \%$ \\
\hline \multicolumn{3}{|l|}{ Type of inhalers } \\
\hline Turbuhaler & 33 & $33 \%$ \\
\hline MDI & 31 & $31 \%$ \\
\hline Handihaler & 36 & $36 \%$ \\
\hline Total & 100 & $100 \%$ \\
\hline
\end{tabular}


Table 5: The percentage of the error in patients using Turbuhaler for each step

\begin{tabular}{|c|c|c|}
\hline Turbuhaler & Steps & Error (\%) \\
\hline 1 & Unscrew and remove cover & 0 \\
\hline 2 & Check dose counter & 60 \\
\hline 3 & $\begin{array}{l}\text { Keep inhaler upright while twisting } \\
\text { grip without shaking }\end{array}$ & 63 \\
\hline 4 & $\begin{array}{l}\text { Twist around and then back until } \\
\text { click is heard }\end{array}$ & 15 \\
\hline 5 & $\begin{array}{l}\text { Breathe out gently, away from the } \\
\text { inhaler }\end{array}$ & 93 \\
\hline 6 & $\begin{array}{l}\text { Place mouthpiece between teeth } \\
\text { without biting and close lips to form } \\
\text { good seal. Do not cover the air vents }\end{array}$ & 39 \\
\hline 7 & Breathe in strongly and deeply & 60 \\
\hline 8 & $\begin{array}{l}\text { Hold breath for about } 5 \mathrm{~s} \text { or as long } \\
\text { as comfortable }\end{array}$ & 81 \\
\hline 9 & Remove inhaler from mouth & 3 \\
\hline 10 & $\begin{array}{l}\text { Breathe out gently, away from the } \\
\text { inhaler }\end{array}$ & 36 \\
\hline 11 & $\begin{array}{l}\text { If an extra dose is needed, repeat } \\
\text { steps } 2-10\end{array}$ & 0 \\
\hline 12 & Replace cover & 0 \\
\hline
\end{tabular}

Table 6: The percentage of the error in patients using MDI for each step

\begin{tabular}{|c|c|c|}
\hline MDI & Steps & Error (\%) \\
\hline 1 & Remove cap & 0 \\
\hline 2 & Hold inhaler upright and shake well & 67 \\
\hline 3 & $\begin{array}{l}\text { Breathe out gently, away from the } \\
\text { inhaler }\end{array}$ & 83 \\
\hline 4 & $\begin{array}{l}\text { Put mouthpiece between teeth } \\
\text { without biting and close lips to form } \\
\text { good seal }\end{array}$ & 25 \\
\hline 5 & $\begin{array}{l}\text { Start to breathe in slowly through } \\
\text { mouth and, at the same time, press } \\
\text { down firmly on canister }\end{array}$ & 19 \\
\hline 6 & $\begin{array}{l}\text { Continue to breathe in slowly and } \\
\text { deeply }\end{array}$ & 90 \\
\hline 7 & $\begin{array}{l}\text { Hold breath for about } 5 \mathrm{~s} \text { or as long } \\
\text { as comfortable }\end{array}$ & 70 \\
\hline 8 & $\begin{array}{l}\text { While holding breath, remove } \\
\text { inhaler from mouth }\end{array}$ & 16 \\
\hline 9 & $\begin{array}{l}\text { Breathe out gently, away from the } \\
\text { inhaler }\end{array}$ & 54 \\
\hline 10 & $\begin{array}{l}\text { If an extra dose is needed, repeat } \\
\text { steps } 2-12\end{array}$ & 6 \\
\hline 11 & Replace cap & 0 \\
\hline
\end{tabular}

MDI: Metered-dose inhaler

This study so, the education about the technique was significantly effective. As show that the technique of MDI uses improved in the two groups that received training in contrast to the control group $(\mathrm{p}<0.001)[21]$

In this study, we noticed that asthmatic patients had a higher but statistically non-significant mean score before and after training than patients with COPD which was similar to the results of some study [22]. While against other study [3] which showed that the COPD patients did better than asthmatic patients, but it was not significant statistically and this may be due to sample size.

The improvement of the score of the patients from urban area was more may be due to less healthcare services and specialized respiratory centers in rural area and they already had more mistakes before education, so they require more sessions of training.
Table 7: The percentage of the error in patients using Handihaler for each step

\begin{tabular}{|c|c|c|}
\hline Handihaler & Steps & Error $(\%)$ \\
\hline 1 & Open cap & 0 \\
\hline 2 & Flip open mouthpiece & 0 \\
\hline 3 & $\begin{array}{l}\text { Remove capsule from blister and } \\
\text { place in chamber }\end{array}$ & 0 \\
\hline 4 & Close mouthpiece in chamber & 2 \\
\hline 5 & $\begin{array}{l}\text { Press piercing button in once and } \\
\text { release (don't shake) }\end{array}$ & 52 \\
\hline 6 & $\begin{array}{l}\text { Breathe out gently, away from the } \\
\text { inhaler }\end{array}$ & 88 \\
\hline 7 & $\begin{array}{l}\text { Place mouthpiece between teeth } \\
\text { without biting and close lips to } \\
\text { form a seal }\end{array}$ & 2 \\
\hline 8 & $\begin{array}{l}\text { Breath in slowly and deeply, so } \\
\text { capsule vibrate }\end{array}$ & 58 \\
\hline 9 & Keep breathing as long as possible & 83 \\
\hline 10 & $\begin{array}{l}\text { While holding breath, remove } \\
\text { inhaler from the mouth }\end{array}$ & 19 \\
\hline 11 & $\begin{array}{l}\text { Breath out gently away from the } \\
\text { inhaler }\end{array}$ & 38 \\
\hline 12 & $\begin{array}{l}\text { Repeat steps from } 7 \text { to } 11 \text { take the } \\
\text { full dose }\end{array}$ & 75 \\
\hline 13 & $\begin{array}{l}\text { Open mouthpiece and remove } \\
\text { capsule }\end{array}$ & 16 \\
\hline 14 & Close mouthpiece and cap & 2 \\
\hline
\end{tabular}

There were significant differences between means of inhaler technique score before and after giving instructions

Table 8: Mean differences of inhaler technique score before and after instructions

\begin{tabular}{|c|c|c|c|c|c|}
\hline $\begin{array}{l}\text { Study } \\
\text { variable }\end{array}$ & $\begin{array}{l}\text { Study } \\
\text { group }\end{array}$ & $\mathbf{N}$ & Mean \pm SD & Paired $t$-test & p value \\
\hline Score & $\begin{array}{l}\text { Before } \\
\text { instructions } \\
\text { A f t e r } \\
\text { instructions }\end{array}$ & $\begin{array}{l}100 \\
100\end{array}$ & $\begin{array}{l}11.46 \pm 2.9 \\
19.05 \pm 1.26\end{array}$ & -31.353 & $<0.001^{*}$ \\
\hline
\end{tabular}

After education, we found that older patients had less mean score may be due to other factors related to older patients as they suffered from larger difficulties to use the device properly because of other comorbidities, lack of dexterity, and also older patients with COPD might had more progressed disease than younger patients with more airways limitation.

The higher educated people had a higher mean score which is consistent with previous study [23] because educated people could read the inhaler leaflet or search about the way of the use of their inhaler on the net.

Even after training, the educated patients and the patients attended the specialized respiratory center still had the highest score this might be explained as those patients already had a higher score before training than the less educated or the people attended the non-specialized center so, they got more benefit from a single session of training. In addition to that, most of the patients attended the specialized respiratory centers were using inhalers, so they might teach each other. Furthermore, the respiratory physician in the specialized centers might have more information about inhaler technique and the most common error of each type of inhalers.

The lowest mean score was for $\mathrm{p}$ MDI $(10.35 \pm 3.05)$ followed by Turbuhaler $(11.39 \pm 2.98)$ and then the Handihaler $(12.47 \pm 2.36)$ 
Table 9: The mean differences of inhaler technique score before instructions according to sociodemographic characteristics

\begin{tabular}{|c|c|c|c|c|c|c|}
\hline Study variable & Study group & $\mathbf{N}$ & Mean \pm SD & t-test & F-test & $P$ value \\
\hline \multirow[t]{2}{*}{ Age (years) } & 60 or more & 34 & $10.97 \pm 2.95$ & -1.213 & & 0.228 \\
\hline & Less than 60 & 66 & $11.71 \pm 2.86$ & & & \\
\hline \multirow{2}{*}{ Gender } & Male & 48 & $11.02 \pm 2.78$ & -1.461 & & 0.147 \\
\hline & Female & 52 & $11.86 \pm 2.97$ & & & \\
\hline \multirow[t]{2}{*}{ Residence } & Urban & 49 & $12.38 \pm 2.89$ & 3.283 & & $0.001^{*}$ \\
\hline & Rural & 51 & $10.56 \pm 2.64$ & & & \\
\hline \multirow[t]{3}{*}{ Educational level } & Uneducated & 14 & $9.14 \pm 2.71$ & & 16.277 & $<0.001^{*}$ \\
\hline & Secondary & 35 & $11.65 \pm 2.33$ & & & \\
\hline & Higher education & 17 & $14.70 \pm 1.86$ & & & \\
\hline \multirow{2}{*}{$\begin{array}{l}\text { Duration of } \\
\text { use (months) }\end{array}$} & 6-12 months & 46 & $11.82 \pm 2.84$ & 1.166 & & 0.247 \\
\hline & More than 1 year & 54 & $11.14 \pm 2.94$ & & & \\
\hline \multirow[t]{2}{*}{ Diagnosis } & Asthma & 43 & $12.02 \pm 3.08$ & 1.701 & & 0.092 \\
\hline & COPD & 57 & $11.03 \pm 2.7$ & & & \\
\hline Type of unit & Specialized center & 60 & $12.05 \pm 2.91$ & 2.557 & & $0.012^{*}$ \\
\hline \multirow[t]{3}{*}{ Type of inhaler } & Turbuhaler & 33 & $11.39 \pm 2.98$ & & 4.78 & $0.01^{*}$ \\
\hline & MDI & 31 & $10.35 \pm 3.05$ & & & \\
\hline & Handihaler & 36 & $12.47 \pm 2.36$ & & & \\
\hline
\end{tabular}

${ }^{*} \mathrm{p} \leq 0.05$ was significant. There was significant positive linear correlation between inhaler technique score and ACT score (r=0.776, $P \leq 0.001 *$ ). COPD: Chronic obstructive pulmonary disease, MDI: Metered-dose inhaler, SD: Standard deviation, ACT: Asthma control test

Table 10: Mean differences of inhaler technique score after instructions according to sociodemographic characteristics

\begin{tabular}{|c|c|c|c|c|c|c|}
\hline Study variable & Study group & $\mathbf{N}$ & Mean \pm SD & t-test & F-test & p value \\
\hline \multirow[t]{2}{*}{ Age (years) } & 60 or more & 34 & $18.61 \pm 1.43$ & -2.323 & & $0.024^{*}$ \\
\hline & $<60$ & 66 & $19.27 \pm 1.11$ & & & \\
\hline \multirow[t]{2}{*}{ Gender } & Male & 48 & $19.02 \pm 1.27$ & -0.22 & & 0.826 \\
\hline & Female & 52 & $19.07 \pm 1.26$ & & & \\
\hline \multirow[t]{2}{*}{ Residence } & Urban & 49 & $19.36 \pm 1.11$ & 2.531 & & $0.013^{*}$ \\
\hline & Rural & 51 & $18.74 \pm 1.33$ & & & \\
\hline \multirow[t]{4}{*}{ Educational level } & Uneducated & 14 & $17.78 \pm 1.05$ & & 11.478 & $<0.001^{*}$ \\
\hline & Primary & 34 & $18.82 \pm 1.35$ & & & \\
\hline & Secondary & 35 & $19.31 \pm 1.10$ & & & \\
\hline & Higher education & 17 & $20.00 \pm 0.00$ & & & \\
\hline \multirow{2}{*}{$\begin{array}{l}\text { Duration of } \\
\text { use (years) }\end{array}$} & 6 months to 1 year & 46 & $19.19 \pm 1.08$ & 1.084 & & 0.281 \\
\hline & More than 1 year & 54 & $18.92 \pm 1.39$ & & & \\
\hline \multirow[t]{2}{*}{ Diagnosis } & Asthma & 43 & $19.32 \pm 1.12$ & 1.961 & & 0.053 \\
\hline & COPD & 57 & $18.84 \pm 1.33$ & & & \\
\hline \multirow[t]{2}{*}{ Type of unit } & Specialized center & 60 & $19.31 \pm 1.04$ & 2.491 & & $0.015^{*}$ \\
\hline & Non-specialized unit & 40 & $18.65 \pm 1.45$ & & & \\
\hline \multirow[t]{3}{*}{ Type of inhaler } & Turbuhaler & 33 & $19.27 \pm 1.008$ & & 6.242 & $0.003 *$ \\
\hline & MDI & 31 & $18.41 \pm 1.60$ & & & \\
\hline & Handihaler & 36 & $19.38 \pm 0.93$ & & & \\
\hline
\end{tabular}

${ }^{*} \mathrm{p} \leq 0.05$ was significant. COPD: Chronic obstructive pulmonary disease, SD: Standard deviatio

before and after training. This is similar to older study [23]. Metereddose inhaler was the hardest to applicate because they need more motor synchronization than DPIs as the drawing of the medication from DPIs devices depend on the force of one's own breath [23].
In this study, we noticed that the low score of the technique of the inhaler use had a substantial influence on the control of asthma (ACT score) and COPD (CAT) score with $\mathrm{p}<0.001$ for both groups which is compatible with other study [24]. 
The findings of this study were similar to other study which concluded that providing instructions by the prescriber is the most adjustable beneficial tool to decrease poor technique of inhaler use [24].

Furthermore, the findings of this study were near these of a study that concluded in spite of long period of inhaler use; the inhaler technique was inadequate and frequent assessing of technique of the use of the inhaler is essential $[25,26]$

\section{Limitation of study}

1. Shortage of time.

2. The convenient sample not presents all the community in Babylon city.

\section{CONCLUSION AND RECOMMENDATION}

1. The p MDI had the lowest mean score (before and after education), so the users need more training on the device.

2. In education need to stress on the most reported defects.

3. Single class of training can be beneficial but need follow-up to see this effect if can be maintained.

4. The most important step with good technique is the education not inhaler type or level of consultation.

5. The correlation of control with good technique is expected.

6. The low technique score is associated significantly with the lower education, people attending primary healthcare centers, and patients from rural area, so those patients need more educational sessions.

7. Elderly patients had more difficulties in the use of the inhaler after education than young patients so we should choose the suitable device to their abilities.

\section{REFERENCES}

1. Al-Jahdali H, Ahmed A, Al-Harbi A, Khan M, Baharoon S, Bin Salih $\mathrm{S}$, et al. Improper inhaler technique is associated with poor asthma control and frequent emergency department visits. Allergy Asthma Clin Immunol 2013;9:8

2. Hardwell A, Barber V, Hargadon T, McKnight E, Holmes J, Levy ML, et al. Technique training does not improve the ability of most patients to use pressurised metered-dose inhalers (pMDIs). Prim Care Respir J 2011;20:92-6.

3. Hasanain G, Abood HA, Al-Mousaw AM, Al-Hatab SJ, Al-Obaidi IA, Abutiheen AA, et al. Technical errors in using inhalers among patients with asthma or COPD in Iraq. Iraqi J Med Sci 2017;15:4-12.

4. Ahmad S, Ismail NE. Stigma in the lives of asthma patients: A review from the literature. Int J Pharm Pharm Sci 2015;7:40-6.

5. Plaza V, Sanchis J. Medical personnel and patient skill in the use of metered dose inhalers: A multicentric study. CESEA group. Respiration 1998;65:195-8.

6. Smyth HD. The influence of formulation variables on the performance of alternative propellant-driven metered dose inhalers. Adv Drug Deliv Rev 2003;55:807-28.

7. Zhou QT, Tang P, Leung SS, Chan JG, Chan HK. Emerging inhalation aerosol devices and strategies: Where are we headed? Adv Drug Deliv Rev 2014;75:3-17.

8. Giner J, Roura P, Torres B, Burgos F, Castillo D, Tarragona E, Plaza V. Knowledge, attitudes and preferences among spanish community pharmacists regarding inhaled therapy (the optim pharmacy study). Int J Pharm Pharm Sci 2016;8:53-60.

9. Murphy A. How to help patients to optimize their inhaler technique. Pharm J 2016;297:7891.

10. Ashurst II, Malton A, Prime D, Sumby B. Latest advances in the development of dry powder inhalers. Pharm Sci Technolo Today 2000;3:246-56.

11. Atkins PJ. Dry powder inhalers: An overview. Respir Care 2005;50:1304-12.

12. Bains BK, Birchall JC, Toon R, Taylor G. In vitro reporter gene transfection via plasmid DNA delivered by metered dose inhaler. J Pharm Sci 2010;99:3089-99.

13. Basheti IA, Armour CL, Bosnic-Anticevich SZ, Reddel HK. Evaluation of a novel educational strategy, including inhaler-based reminder labels, to improve asthma inhaler technique. Patient Educ Couns 2011;

14. Basheti IA, Reddel HK, Armour CL, Bosnic-Anticevich SZ. Improved asthma outcomes with a simple inhaler technique intervention by community pharmacists. J Allergy Clin Immunol 2007;119:1537-8.

15. Bjermer L. The importance of continuity in inhaler device choice for asthma and chronic obstructive pulmonary disease. Respiration 2014;88:346-52.

16. Bosnic-Anticevich SZ, Sinha H, So S, Reddel HK. Metered-dose inhaler technique: The effect of two educational interventions delivered in community pharmacy over time. J Asthma 2010;47:251-6.

17. British Thoracic Society/Scottish Intercollegiate Guidelines Network. British Guideline on the Management of Asthma. Clinical Guideline No. 141; 2014. Available from: https://www.brit-thoracic.org.uk/ document-library/clinical.

18. Center of Disease Control and Prevention; 2017. Available from: https://www.cdc.gov/nchs/fastats/leading-causes-of-death.htm.

19. Crompton GK, Barnes PJ, Broeders M, Corrigan C, Corbetta L, Dekhuijzen $\mathrm{R}$, et al. The need to improve inhalation technique in europe: A report from the aerosol drug management improvement team. Respir Med 2006;100:1479-94

20. van der Palen J, Thomas M, Chrystyn H, Sharma RK, van der Valk PD, Goosens M, et al. A randomised open-label cross-over study of inhaler errors, preference and time to achieve correct inhaler use in patients with COPD or asthma: Comparison of ELLIPTA with other inhaler devices. NPJ Prim Care Respir Med 2016;26:16079.

21. Al-Showair RA, Tarsin WY, Assi KH, Pearson SB, Chrystyn H. Can all patients with COPD use the correct inhalation flow with all inhalers and does training help? Respir Med 2007;101:2395-401

22. Souza ML, Meneghini AC, Ferraz E, Vianna EO, Borges MC. Knowledge of and technique for using inhalation devices among asthma patients and COPD patients. J Bras Pneumol 2009;35:824-31.

23. Rahmati H, Ansarfard F, Ghodsbin F, Ghayumi MA, Sayadi M. The effect of training inhalation technique with or without spacer on maximum expiratory flow rate and inhaler usage skills in asthmatic patients: A Randomized controlled trial. Int J Community Based Nurs Midwifery 2014;2:211-9.

24. Madkour A, Galal I. Do egyptian patients use their inhalers correctly? A checklist auditing for inhalation devices usage techniques. Egypt J Chest Dis Tuberc 2015;64:497-504.

25. Dalcin Pde T, Grutcki DM, Laporte PP, Lima PB, Menegotto SM, Pereira RP, et al. Factors related to the incorrect use of inhalers by asthma patients. J Bras Pneumol 2014;40:13-20.

26. Melani AS, Bonavia M, Cilenti V, Cinti C, Lodi M, Martucci P, et al. Inhaler mishandling remains common in real life and is associated with reduced disease control. Respir Med J 2011;105:930-8 